Litteratur

1. Dobloug JH. Hvem vokter vokterne? Legeetikk i forsikringsmedisinen. Tidsskr Nor Legeforen 2013; 133: 320-1

2. Hem E. Hvorfor har dere skrevet om meg uten å spørre? Tidsskr Nor Legeforen 2013; 133: 261

3. LOV 1999-07-02 nr 64: Lov om helsepersonell m.v. (helsepersonelloven). § 27 www.lovdata.no/all/hl-19990702-064.html (8.3.2013)

Dette er en redigert versjon av et innlegg publisert som rask respons på nett 7.2.2013 http://tidsskriftet.no/article/2968488

\section{Preoperative nakkebilder hos voksne med Downs syndrom?}

I Tidsskriftet nr. 3/2013 presenterer Eva A. Malt og medarbeidere en ryddig oversikt over helseproblemer hos voksne med Downs syndrom (1). Det er prisverdig at forfatterne også tar opp forhold som er viktig å kjenne til spesielt for anestesiologer. Like fullt er det grunn til å stille spørsmål ved et utsagn, som også er gjengitt i sammendraget: «Atlantoaksial instabilitet forekommer, og det skal utføres radiologisk undersøkelse av nakken før inngrep i narkose.» Anestesiologer er vel kjent med at det er en økt risiko for instabilitet i nakken hos pasienter med Downs syndrom, men er overrasket over kravet til rutinemessig preoperativ radiologisk screening ved denne lidelsen.

En rask spørrerunde i februar 2013 avdekket at anestesiavdelingene ved universitetssykehusene ikke har nedfelt i sine prosedyrer at det skal tas rutinemessig preoperative røntgenbilder av nakken hos voksne med Downs syndrom. Det ser heller ikke ut til å foreligge internasjonale retningslinjer som støtter screening av asymptomatiske voksne pasienter (2). Ikke sjelden er det dessuten slik at indikasjonen for narkose hos pasienter med Downs syndrom nettopp er å få gjort adekvat utredning, f.eks. radiologisk diagnostikk. Det er naturlig å spørre hvilket kunnskapsgrunnlag som ligger bak kravet om radiologisk screening.

Røntgenbilder vil uansett ikke med $100 \%$ sensitivitet avdekke en eventuell tendens til glidning, og langt de fleste rapporterte nakkeskader i forbindelse med kirurgi hos pasienter med stabile forhold i nakken (3). God anestesiologisk praksis tilsier derfor at man unngår intubasjon hvis andre muligheter for tilfredsstillende luftveissikring finnes, og at man behandler nakken skånsomt med minst mulig bevegelser hos alle pasienter og med spesiell årvåkenhet ved Downs syndrom. Radiologisk forundersøkelse gjøres etter vurdering av pasienten, den planlagte luftveissikringen og leiringen under inngrepet. I vurderingen inngår hvorvidt tidligere utredning av pasienten har avdekket patologi i nakken.

Kunnskapsbaserte retningslinjer for vurdering av risiko for nakkeglidning er etterspurt, også internasjonalt (2). Skulle det fremkomme dokumentasjon som gjør at krav til anestesiologisk praksis og prosedyrer bør endres, er det naturlig at det skjer i samarbeid med våre faglige organer og ikke som en konklusjon i en oversiktsartikkel fra andre fagmiljøer.

Siv Cathrine Høymork

sch@kunnskapssenteret.no Johan Ræder

Siv Cathrine Høymork (f. 1965) anestesiolog og avdelingsdirektør ved Nasjonalt kunnskapssenter for helsetjenesten. Ingen oppgitte interessekonflikter.

Johan Ræder (f. 1954) er overlege og professor ved Avdeling for anestesiologi, Oslo universitetssykehus og Institutt for klinisk medisin, Universitetet i Oslo.

Ingen oppgitte interessekonflikter.
Litteratur

1. Malt EA, Dahl RC, Haugsand TM et al. Helse og sykdom hos voksne med Downs syndrom. Tidsskr Nor Legeforen 2013; 133: 290-4

2. Hata T. Todd MM. Cervical spine considerations when anesthetizing patients with Down syndrome. Anesthesiology 2005: 102: 680-5.

3. Hindman BJ, Palecek JP, Posner KL et al. Cervical spinal cord, root, and bony spine injuries: a closed claims analysis. Anesthesiology 2011; 114: 782-95.

Dette er en redigert versjon av et innlegg publisert som rask respons på nett 13.2. 2013 http://tidsskriftet.no/article/2966533

\section{Autisme ved Downs syndrom}

I Tidsskriftet nr. 3/2013 sto en interessant oversiktsartikkel av Eva A. Malt og medarbeidere om voksne med Downs syndrom (1). Jeg ønsker å supplere avsnittet om sentralnervesystemet med et fenomen som har vært lite påaktet når det gjelder personer med Downs syndrom: At en ikke liten andel av disse personene samtidig har autisme. Moss og medarbeidere fant i sin studie av 108 personer med Downs syndrom en forekomst på $19 \%$ for autismespekterforstyrrelser og $8 \%$ for autisme (2). Rasmussen og medarbeidere formulerte det slik: «autism is by no means rare in DS. Results showed that there was a considerable delay in the diagnosis of autism as compared with children with autism who did not have DS.» (3).

Autismeenheten skriver at ett av særtrekkene hos disse pasientene med dobbeltdiagnose er at språkutviklingen viser et relativt raskt fall i både ordforråd og grammatikk i aldersgruppen 14-19 år (4). Sterkt forlenget latenstid er også et typisk trekk. Personene i utvalget til Autismeenheten er beskrevet som mer atletiske og mindre hypotone enn det som vanligvis er tilfellet med personer med Downs syndrom. Man ser ikke den «sosiale» oppførselen og personligheten som ellers er typisk ved Downs syndrom. Pasientene har en passiv reaksjon på uventede hendelser og generelt høy grad av passitivitet.

Min erfaring fra Helse Bergen er at svært få voksne med Downs syndrom har fătt diagnostisert autisme. Etter min mening foreligger det sannsynligvis en betydelig underdiagnostisering, og vi må være åpne for at en del av de pasientene vi møter som har Downs syndrom og «vanskelig» atferd, kan ha udiagnostisert autisme.

\section{Jack Schjelderup \\ jack.schjelderup@helse-bergen.no}

Jack Schjelderup (f. 1956) er overlege ved Habiliteringstjenesten for voksne, Haukeland universitetssykehus.

Ingen oppgitte interessekonflikter.

\section{Litteratur}

1. Malt EA, Dahl RC, Haugsand TM et al. Helse og sykdom hos voksne med Downs syndrom. Tidsskr Nor Legeforen 2013; 133: $290-4$

2. Moss J, Richards C. Nelson L et al. Prevalence of autism spectrum disorder symptomatology and related behavioural characteristics in individuals with Down syndrome. Autism 2012; e-publisert 15.5.2012.

3. Rasmussen P, Börjesson O, Wentz E et al. Autistic disorders in Down syndrome: background factors and clinical correlates. Dev Med Child Neurol 2001; 43: $750-4$.

4. Barn og unge med Down syndrom og autisme. Oslo: Nasjonal kompetanseenhet for autisme (Autismeenheten), 2011.

Dette er en redigert versjon av et innlegg publisert som rask respons på nett 13.2. 2013 http://tidsskriftet.no/article/2966533

\section{E. A. Malt svarer:}

Takk for utdyping og presisering vedrørende rutinemessige preoperative nakkebilder hos personer med Downs syndrom. Vår intensjon er ikke å introdusere nye retningslinjer for preoperative rutiner for denne gruppen. Vi ønsker imidlertid å minne klinikere, og da spesielt fastlegene, om at atlantoaksial instabilitet kan være bakenforliggende årsak til tidlige tegn og symptomer på kompresjon av 